\title{
HUNGARIAN ENDEAVOURS FOR THE ENHANCEMENT OF ECONOMIC RELATIONS IN SOUTHEAST ASIA FOCUSING ON A NEW PARTNERSHIP WITH VIETNAM
}

\author{
László Kozár ${ }^{1}$ - György Iván Neszmélyi ${ }^{2}$ \\ ${ }^{1}$ Professor, Head of Institute of Commerce, Budapest Business School - University of Applied Sciences \\ ${ }^{2}$ Associate Professor, Institute of Commerce, Budapest Business School - University of Applied Sciences
}

\begin{abstract}
Beyond a brief review of the economic integration process among the states of the ASEAN region, the authors of the present study aimed to examine and analyze the main economic, social and political characteristics of the Hungaro-ASEAN relations. The importance of the topic of this research is underlined by the fact that the Hungarian government considers big importance to the improvement of the foreign economic relations with Asian economies. This intention was expressed by a new foreign economic strategy „Eastern opening” announced by the government in 2012, even though the foreign trade statistical figures did not justify its success by now.

The authors believe that increasing opening towards Asia serves Hungarian economic interests. Therefore, it is a right and desirable direction to proceed, they consider that in the background of the modest results there might be the insufficient knowledge of the market mechanisms, the actors of the local supply chains and the potential partners. They believe that in order to make the Hungarian foreign economic endeavours in this direction more successful a more thorough examination of the local characteristics - including the actual demand arising at the targeted markets - is necessary. This opinion is prevalent to not only the Asian „Giants”, like China, India and Japan, but also to smaller states, like the ASEAN members, which - together - in terms of population and economic performance - reach the dimensions of an economic great power as well.

Furthermore, the integration of the ten Southeast Asian countries develops rapidly, which is coupled by their increasing weight in the world trade. The dynamic economic and social development in the ASEAN region - and in parallel with this the growing demands and purchasing power - may encourage the Hungarian ventures in theory. However, there are still very few Hungarian entrepreneurs, who are ready to enter the market in the region and able in long run to operate there successfully.

It is a well-known fact that the since the regime has changed in Hungary, foreign trade became strongly concentrated towards the EU members. The ASEAN countries - because of the geographic distance and by other reasons - definitely cannot mean an alternative of the EU market, however in a certain extent they can relieve this one-sided concentration and may provide additional opportunities for the Hungarian export of goods, and rather to the export of Hungarian services and know-how.

The ratio of the ASEAN region within the entire Hungarian foreign trade turnover is small nowadays, furthermore - according to the statistical figures - this region is rather an import resource for Hungary than being an export market. This fact - just itself - is should not be considered as problem. When the amount of the import exceeds the amount of exports, that means that it is more worthwhile to do business with suppliers from there countries than with others.

By and large all this is prevalent to the field of the agricultural trade as well: Hungary imports a range of commodities which cannot be produced by domestic farmers or in Europe (spices, tropical fruits, etc.).

It is obvious that the ASEAN region cannot be the major market for the Hungarian agricultural export, not even in long run. However, there are still a lot of opportunities to enlarge the turnover of goods and services and enhance the co-operation in this geographic region. In the last chapter, the authors outlined an example in case of Vietnam - co-operation of joint public warehousing of agricultural commodities - which may be a good example for the promising potential opportunities.

In contrast with the majority of the ASEAN countries, the Hungaro-Vietnamese political and economic relations had started much earlier than the regime was changed in Hungary. However, the potential advantages arose from this fact - the network of connections and the sympathy of Vietnamese professionals graduated in Hungary, the reputation and popularity of Hungarian agricultural products and technologies, the achievements of $R \& D$ in the field of agriculture - could not be utilized from Hungarian side. Vietnam, however still preserved its socialist political establishment, but in terms of its economic development strategy and economic policy has gradually been standing on the basis of market orientation. Vietnam, with its population of ninety million shows a rapid and successful development and it means good opportunities even for Hungarian entrepreneurs. It would be a mistake to leave these potentials unused.
\end{abstract}

Keywords: Southeast Asia, Europe, Regional integration, Eastern opening, Trade (JEL Classification: F 14, Q17, R11, N75) 


\section{INTRODUCTION}

Soon the $50^{\text {th }}$ anniversary of the day will be celebrated when - on the $8^{\text {th }}$ August, 1967 - five developing countries of Southeast-Asia (the Philippines, Indonesia, Malaysia, Singapore and Thailand) signed the Bangkok Declaration, which launched a loose alliance of governments - the Association of South-East Asian Nations (ASEAN). The Permanent Secretariat of ASEAN resides in Jakarta, the capital city of Indonesia. Brunei, after having gained her independence, joined the organisation in 1984, Vietnam in 1995 and Laos and Myanmar in 1997 and at last Cambodia joined to the Association in 1999.

The declared aims of this regional organisation are the promotion of economic growth and the acceleration of social and cultural development in the region. However, there were also other important political and security considerations for creating ASEAN, which included: a) prevention of political conflicts in the region, which could lead to, or provoke the intervention of an outside power, b) to create a forum for handling disputes between member nations, c) to bring stability to the social and economic systems of the member nations.

Despite the current financial crisis in the Far East the ASEAN region has managed to hold its position as one of the most dynamically developing regions in the world economy. The member states express a keen interest in broadening the forms of cooperation among themselves. In January, 1992 ASEAN announced the future development of AFTA (ASEAN Free Trade Area) for the period 1993 to 2008, with the gradual phasing out of customs restrictions within the Association. In 1995 the deadline for the completion of AFTA was brought forward to 2003.

In the course of the half-century history of the Association, ASEAN members have been among the most spectacularly developing countries in the world. According to competent analysts, the economy has been continuing to grow rapidly in the forthcoming years (see figures of Table 1). The member countries in total represent a population of 622 million people, which - in case of the continuation of the economic growth and increasing incomes - bodes for considerable growth in consumption for the coming decades. According to its population ASEAN is bigger than the European Union or the United States, it is the $3^{\text {rd }}$ largest market in the world, behind only India and China. ASEAN is a fast growing and promising region. Its total trade increased by nearly USD 1 trillion between 2007 and 2014, with intra-ASEAN trade comprising the largest share of ASEAN's total trade by partner. ASEAN attracted USD 136 billion in FDI in 2014, accounting for 11\% of global FDI inflows, up from only 5\% in 2007.

The most recent milestone in the economic integration process of Southeast Asia was formal establishment of the ASEAN Economic Community (AEC) on 31 ${ }^{\text {st }}$ December 2015 which was built on four interrelated and mutually-reinforcing characteristics: (a) a single market and production base, (b) a highly competitive economic region, (c) a region of equitable economic development, and (d) a region fully integrated into the global economy. ASEAN is nowadays is a highly competitive economic region in the world with a combined GDP of USD 2.6 trillion in 2014, ASEAN economy was $7^{\text {th }}$ largest in the world and the the $3^{\text {rd }}$ largest in Asia. The formal establishment of the AEC in 2015 is not a static end goal, but a dynamic process that requires continuous reinvention of the region to maintain its relevance in an evolving global economy. The agenda "AEC Blueprint 2025" has therefore been adopted to guide ASEAN economic integration from 2016 to 2025 (Fact Sheet on ASEAN Economic Community, 2015).

Table 1: Key economic data for the ASEAN member countries (2016)

\begin{tabular}{|c|c|c|c|c|c|c|}
\hline 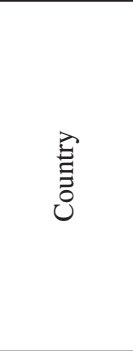 & 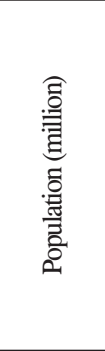 & 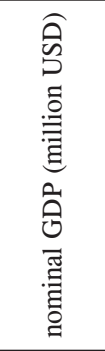 & 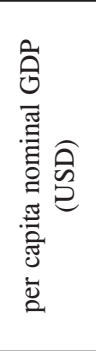 & 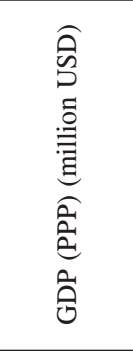 & 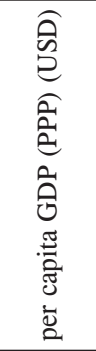 & $\begin{array}{c}\text { Trend } \\
\text { rate of } \\
\text { annual } \\
\text { economic } \\
\text { growth } \\
\text { (real } \\
\text { GDP, } \\
2013- \\
2018 \\
(\%)^{*}\end{array}$ \\
\hline Brunei & 417 & 10,458 & 30,993 & 35,817 & 83,513 & 5.64 \\
\hline Philippines & 103.701 & 311,687 & 3,002 & 873,966 & 8,224 & 3.10 \\
\hline Indonesia & 260.581 & 940,953 & 3,362 & $3,256,730$ & 12,422 & 7.44 \\
\hline Cambodia & 15.626 & 19,476 & 1,144 & 64,365 & 4,020 & 6.18 \\
\hline Laos & 6.492 & 13,761 & 1,787 & 44,880 & 6,149 & 7.35 \\
\hline Malaysia & 31.973 & 302,748 & 9,501 & 922,894 & 28,612 & 5.64 \\
\hline Myanmar & 54.363 & 68,277 & 1,212 & 342,205 & 6,501 & 7.06 \\
\hline Singapore & 5.607 & 296,642 & 52,888 & 508,449 & 90,249 & 5.94 \\
\hline Thailand & 68.147 & 390,592 & 5,742 & $1,246,640$ & 17,731 & 4.76 \\
\hline Vietnam & 92.700 & 205,860 & 2,088 & 645,333 & 6,895 & 4.49 \\
\hline
\end{tabular}

Source: Brian W. (2017.), on the basis of IMF estimations in October 2016 (*: on the basis of data of Kinbiz online and of the Economist Intelligence Unit)

\section{MATERIAL AND METHOD}

The present paper aimed to explore the economic, social and political attributes by descriptive analysis based mainly on results and information of secondary research being gained from bibliographic sources and databases. In addition, it needs to be mentioned that both authors used to work in the field of the development of the economic and political relations with various ASEAN countries therefore their direct experiences could also mean a contribution to this study. The data which are used in this study were received from the Hungarian Research Institute of Agricultural Economics (AKI), from the Central Statistical Office (KSH), the Ministry of Agriculture and Rural Development (MARD) of Vietnam, while the prices of commodities were published by ICE, NASDAQ, IG UK and the CME Group.

In case of the agricultural trade the authors had to rely 
on the classification of the Hungarian statistical trade system which uses four categories as follows: I. Alive animals, animal products (01-05) II. Plant products (06-14), III. Animal and plant fat, oil and wax (15) and IV. Food products, beverages and tobacco (16-24). Even though this classification does not comprise several types of goods, especially various raw materials, which may have either agricultural or mineral origin the statistical system does not make a proper differentiation among them. However, the aggregate figures deriving from the sum of the mentioned four categories of products can well represent the trends and approximate figures of the agricultural trade.

\section{The main trends in foreign trade}

Hungary's relations to some countries of the ASEAN region were already established in the 1950's and 1960's. The partnerships to Vietnam, and the previously socialist Cambodia and Laos can by now be seen as well established (bearing in mind that behind the development of political and economic relations stood the interests of the Socialist Bloc, representing the interests of the Soviet Union, not particularly Hungary).

Hungary's relations to the other countries in the region have been more recent. Relations started developing with Thailand, Malaysia and Singapore in the 1980's and 90's. Although an economic partnership was formed with Indonesia in the second half of the 1950's, this relationship was setback by the political changes there in 1965 , and only began developing again in the second part of the 1980's. Hungary has very modest economic relations with the other two ASEAN nations,
Brunei and Myanmar. Hungary never had particular contacts with Brunei, but used to have more intense connections with the once "socialist" Burma until the end of the eighties. The ruling military junta and the international political isolation of Myanmar since 1988 have provided an unfavourable economic environment for the maintenance of previous relations.

The aim of this paper is to explore the importance of the Asia and within Asia the ASEAN region with the view of suggesting diversification of the foreign market structure as it has been strongly focused on the European Union. In 2015 $79.2 \%$ of Hungarian exports were dispatched to and $76.5 \%$ of Hungarian imports derived from the member states of the European Union. Asian countries - including China, India, Japan, ASEAN members and other countries - totaled in $5.7 \%$ in Hungarian exports and $12.8 \%$ (Külkereskedelem 2015, KSH, 2016). According to Zéman, Z. (2017) in setting strategic objectives and issues it is useful to make distinction between strategic and tactical decisions. Strategic decisions receive a wide range of support, the are qualitative types of decisions, which include or reflect the goals and objectives. Our suggestion coincides with the intention of the Hungarian government which has recently launched its new foreign economic strategy called Eastern opening and Southern opening with the view of increasing trade activity with Asian, African and Latin-American countries.

Foreign trade with the surveyed region was compared with the total volume of Hungarian foreign trade. The data in Tables 2 and 3 shows that trade with ASEAN countries represented only a small and slightly shrinking fraction of the total of Hungary's foreign trade turnover, although it is evident that Hungarian imports exceeded the exports to the

Table 2: Hungarian exports to the Southeast Asian region (USD)

\begin{tabular}{|c|c|c|c|c|c|c|}
\hline & 2010 & 2011 & 2012 & 2013 & 2014 & 2015 \\
\hline Brunei & 239.262 & 399.570 & 323.727 & 178.081 & 2.501 .108 & 1.466 .158 \\
\hline Indonesia & 64.077 .078 & 71.552 .975 & 24.039 .680 & 38.986 .581 & 36.943 .548 & 49.067 .893 \\
\hline Cambodia & 146.139 & 261.968 & 6.078 .143 & 1.269 .448 & 255.204 & 795.384 \\
\hline Laos & 4.912 .772 & 13.032 & 21.598 & 73.772 & 403.117 & 316.676 \\
\hline Myanmar & 175.901 & 20.583 & 27.280 .316 & 1.112 .443 & 4.025 .484 & 4.465 .280 \\
\hline Malaysia & 96.170 .718 & 235.488 .083 & 158.124 .885 & 137.660 .396 & 117.013 .864 & 116.483 .549 \\
\hline Philippines & 29.430 .985 & 6.719 .789 & 14.218 .040 & 9.424 .727 & 14.814 .028 & 17.439 .317 \\
\hline Singapore & 587.059 .160 & 835.326 .282 & 402.014 .248 & 284.561 .368 & 209.852 .740 & 195.683 .123 \\
\hline Thailand & 126.618 .518 & 200.581 .854 & 119.231 .106 & 71.355 .030 & 92.961 .587 & 85.136 .390 \\
\hline $\begin{array}{c}\text { Vietnam } \\
\text { ASEAN total }\end{array}$ & 41.891 .118 & 45.627 .861 & 44.024 .932 & 59.600 .513 & 85.245 .257 & 67.188 .205 \\
\hline $\begin{array}{c}\text { Total } \\
\text { Hungarian } \\
\text { Exports }\end{array}$ & 94.749 .270 .305 & 111.217 .664 .285 & 102.830 .359 .466 & 108.014 .977 .779 & 112.536 .910 .627 & 100.299 .052 .690 \\
\hline $\begin{array}{c}\text { ASEAN } \\
\text { proportion of } \\
\text { the above }\end{array}$ & 1,00 & 1.395 .991 .997 & 795.356 .675 & 604.222 .359 & 564.015 .937 & 538.041 .975 \\
\hline
\end{tabular}


region between 2010 and 2015. During this period both total Hungarian exports and imports grew (the total exports from around 94.7 to 100.3 bln USD, imports 87.4 to 90.7 bln USD).

It would be difficult to discover straight trends as figures altered from year to year, but in terms of Hungarian exports to ASEAN countries it looks that the top year was 2011 (almost 1.4 bln USD) and from then a shrinking trend can be seen until 2015 (538 M USD). In terms of Hungarian exports to ASEAN the shrinking trend can be explained mostly with the drop in Hungarian exports to Singapore, Thailand and Malaysia. Hungarian exports started to grow to Myanmar and Brunei during these years from nearly ground zero, but besides them the only ASEAN country is Vietnam, where Hungarian exports grew since 2010. It also looks well that from the point of Hungarian exports to ASEAN the top year was 2011. As for the import figures we may also decline during this period (from around 1.8 bln USD to a bit less than 1.5 bln USD). Hungarian imports from several ASEAN countries (Indonesia, Malaysia, Thailand and Vietnam) grew during this six-year period while shrinking imports could be seen from Singapore and the Philippines). In spite of the fact that ASEAN region has a small share within the Hungarian foreign trade activity, there are several countries where trade relations and other types of co-operation have been steadily growing. The best example for the latter is Vietnam.

It is also worthwhile to see what can be the reasons of the relatively low and shrinking figures of the export performance of Hungary to this region. A previous research (Neszmélyi, 1999) pointed out the comprehensive political and economic metamorphosis in Hungary during the early 1990' when the fragmentation privatization of the former, state owned Hungarian foreign trade companies narrowed the new business entities' econo-geographic radius, and the increasing focus on the European markets.
Kiss, J. (1993) refers to another previous research, undertaken by Gáspár and Sass at the beginning of the nineties, suggested that the poor export performance of Hungary to the Southeast-Asian region was largely due to the country's export-structure, as the exports mostly consisted of on mass-products with a high demand of resource inputs (raw materials, semi-finished products) and high transporting costs. But since then - during the recent 20-25 years - a lot of things changed. Hungary is a well functioning market economy which successfully overcame the negative impacts of the economic crisis of 2008-2009, and during the examined period in macro-figures the overall trend is positive. Besides the considerable geographic distance and the different business culture (Madlenak and Madlenakova, 2015) (another reason might be the lack of capital might prevent Hungarian SMEs to open towards Southeast Asia as exporters or even in capacity of FDI investors. Behind the growing in imports there lies a global trend in diversification. This can be seen, for example, by the export of certain vehicles or semi-conductors from Malaysia or Singapore, which are less expensive than from other sources.

\section{The characteristics of Hungary's agricultural trade with the Southeast Asian region}

Much of the land mass of the ASEAN countries is situated in the tropical zone, so this region may serve as a source of imports for Hungary for products and crops which cannot be grown domestically. The most important goods are: spices, cocoa, coffee, certain tropical fruits. The export of Hungarian food to the region is by comparison very modest. The export of bulk products (e.g. cereals), incur very high transportation costs due to the great distances involved. Added to this, Hungary can not compete with goods of many bigger

Table 3: Hungarian imports from the Southeast-Asian region (USD)

\begin{tabular}{|c|c|c|c|c|c|c|}
\hline & 2010 & 2011 & 2012 & 2013 & 2014 & 2015 \\
\hline Brunei & 2.537 & 495 & 39 & & 1.080 & 59 \\
\hline Indonesia & 74.556 .978 & 107.690 .891 & 66.469 .580 & 95.901 .942 & 121.997 .745 & 141.997 .110 \\
\hline Cambodia & 52.632 & 545.063 & 505.213 & 291.557 & 9.430 & 330.237 \\
\hline Laos & 3.780 & 362 & & 12.002 & 3.063 & 24.444 \\
\hline Myanmar & 11.179 & 11.296 & & 351.881 & 47.970 & 48.441 \\
\hline Malaysia & 161.000 .953 & 240.425 .243 & 326.451 .804 & 208.890 .971 & 253.097 .678 & 320.958 .023 \\
\hline Philippines & 313.637 .209 & 212.476 .025 & 161.000 .043 & 156.790 .818 & 177.567 .781 & 189.065 .595 \\
\hline Singapore & 952.648 .628 & 854.215 .891 & 583.517 .900 & 622.609 .987 & 514.374 .090 & 331.428 .521 \\
\hline Thailand & 270.355 .693 & 284.681 .307 & 293.178 .869 & 378.863 .015 & 379.446 .263 & 420.125 .493 \\
\hline Vietnam & 28.409 .426 & 35.974 .957 & 44.630 .786 & 48.650 .438 & 50.557 .933 & 75.670 .728 \\
\hline $\begin{array}{c}\text { ASEAN total } \\
\text { Total Hungarian } \\
\text { Imports }\end{array}$ & 1.800 .679 .015 & 1.736 .021 .530 & 1.475 .754 .234 & 1.512 .362 .611 & 1.497 .103 .033 & 1.479 .648 .651 \\
\hline $\begin{array}{c}\text { ASEAN proportion } \\
\text { of the above }\end{array}$ & 2,06 & 101.375 .449 .297 & 94.307 .658 .338 & 99.307 .020 .938 & 104.188 .086 .493 & 90.770 .226 .393 \\
\hline
\end{tabular}

Source: Own compilation from data of the Research Institute of Agricultural Economy (AKI), Budapest, 2016 
countries, like American products which are shipped to Asia in large scale at more reasonable costs and prices or even as aid. However, despite this during the recent decades it happened that Hungary did manage to export even wheat to the region (for example to Indonesia), on several occasions. However, the majority of the profit from such trade goes to middlemen.

The prospects are better for highly processed goods, although problems are also associated with these. Potential exporters tend to be ignorant or ill-informed of local tastes and market conditions (channels, market regulations, etc). Hungarian entrepreneurs can not generally afford market opening business, with the associated traveling and marketing costs, market research, etc. Most of them find the cost of breaking into the markets either too high or too risky.

But, as Erdei-Késmárki-Gally Sz. and Fenyvesi L. (2012) underlined there is a continuous growth of food consumption in the world, there is a growing demand for agricultural produce and food (this effect is significant in certain developing countries) and simultaneously there is more and more demand for producing industrial raw materials and developing 'non-food' agricultural crops (Erdei-KésmárkiGally Sz. and Fenyvesi L. 2012).

According to Zsarnóczai J. S. the improvement of the food security thus the increase of food safety is an issue of basic importance thus - using the international, e.g. from the possibility of projects being supported by resources of the European Union, it is an important task to find the most efficient ways of the spreading of advanced technologies and modern methods (Zsarnóczai J. S. 1997, 1979).

However, it is positive fact that in the recent years Hungary re-opened several diplomatic missions and commercial representation offices in the region (like in Kuala Lumpur and Ho Chi Minh City) so their on-site activity might generate positive value added in the trade turnover and also in the field of the bilateral FDI relations with these countries.

When we have a look at the figures of the Hungarian export to the ASEAN countries, it is well visible that proportionally it is a relatively low fraction within the amount of entire Hungarian agro-export. However, there can be seen a growing trend as from 2010 to 2015 its value has been more than tripled (from about 9,1 M USD to 32,1 M USD), while the overall Hungarian agricultural export also grew during this period, but at a lower extent (from about 7,8 bln USD to 8,8 bln USD). It is also visible that the main export market of these goods for Hungary is Vietnam. From 2010 to 2015 the overall agricultural imports to Hungary also grew, from about $4,9 \mathrm{bln}$ USD to 5,4 bln, and also agricultural imports from ASEAN region also grew from $23 \mathrm{M}$ USD to $30 \mathrm{M}$ USD. It has to be added as well that both export and import figures were higher in years from 2011 to 2014 than in 2010 or in 2015. The biggest source of agricultural imports for Hungary from the ASEAN region was Malaysia in this period, Indonesia, Thailand and Vietnam are also significant import sources (Tables 4 and 5).

Aside from direct trade, or trade through intermediaries, there are also other possible opportunities for advantageous cooperation in the agricultural food industry sphere, for example, the setting-up of joint venture companies, or research and development collaborations. In Thailand there is a government scheme to turn the opium plantations in the northern part of the country into areas for the cultivation of other crops of the temperate climate zone. In the Philippines there is also a central project to improve the quality characteristics of maize production - in the case of both of these, Hungarian expertise could be used. With regard to Vietnam, the "traditional" relationship, based on the former "socialist fraternity" has successfully been converted to a new,

Table 4: Hungarian agricultural exports to the Southeast-Asian region (million USD)

\begin{tabular}{|c|c|c|c|c|c|c|}
\hline & 2010 & 2011 & 2012 & 2013 & 2014 & 0 \\
\hline Brunei & 0 & 0 & 0 & 0 & 015 \\
\hline Indonesia & 269.592 & 636.742 & 411.446 & 551.976 & 2.157 .354 & 3.269 .075 \\
\hline Cambodia & 38.699 & 49 & 0 & 67.473 & 11 & 57.593 \\
\hline Laos & 0 & 0 & 0 & 18.094 & 0 & 0 \\
\hline Myanmar & 0 & 8.328 & 0 & 0 & 2.034 .556 & 3.683 .969 \\
\hline Malaysia & 9.495 & 172.091 & 494.126 & 401.483 & 1.244 .669 & 2.545 .611 \\
\hline Philippines & 44.829 & 48.171 & 46.420 & 94.628 & 171.562 & 45.040 \\
\hline Singapore & 755.537 & 1.498 .705 & 2.813 .152 & 3.813 .399 & 7.414 .559 & 4.712 .311 \\
\hline Thailand & 382.155 & 458.421 & 726.579 & 669.014 & 1.116 .534 & 1.744 .439 \\
\hline Vietnam & 7.628 .148 & 6.877 .315 & 1.951 .294 & 4.023 .578 & 20.704 .172 & 16.052 .937 \\
\hline ASEAN total & 9.128 .455 & 9.699 .822 & 6.443 .017 & 9.639 .645 & 34.843 .417 & 32.110 .975 \\
\hline Total Hungarian agro-export & 7.758 .703 .876 & 10.004 .239 .672 & 10.373 .175 .097 & 10.637 .476 .999 & 10.274 .086 .113 & 8.774 .143 .170 \\
\hline ASEAN proportion of the above & 0,12 & 0,10 & 0,06 & 0,09 & 0,34 & 0,37 \\
\hline
\end{tabular}


business-oriented type of relationship which was extended to various fields of business. In the field of agriculture mention must be made about experiments to introduce Hungarian seed varieties, for example hybrid maize, vegetables and fruits into the market, as well as to produce from Hungarian seeds in cooperation with Vietnamese partners. Another co-operation initiative in the field of animal feed manufacturing in the frames of a joint venture is under elaboration.

\section{Proposal for entering the Vietnamese market by a Hungarian know-how export}

The international competition is really sharp on the market of V ietnam - the country with its 95 million inhabitants and Hungarian companies do not have an easy job to cope with J apanese, South K orean, A merican, G erman, or Chinese competitors who are present there and whose market share is remarkable. There were a significant number of Vietnamese students who graduated at Hungarian universities, including the agricultural higher education from the nineteen-si xties to the change of political system. M ost of these alumni students are retired by now, even though many of them used to be in important positions either in corporate managers or leading governmental officials so they could have been catalysts of the broadening of partnerships in the last quarter century. Hungary failed to take advantage of this opportunity, thus it has to rely on this human basis which is more and more li mited for the future from now. However, based on our personal experience gained in the last five years we can declare, this market provides still plenty of opportunities for the Hungarian knowledge-export. Regarding this, the authors intend to briefly introduce an ow $n$ research-based know-how export possibility which could be a basis of a well elaborated business proposal.

Public Warehousing and the warehouse recipe, as collateral, based Lombard Financing are special storing/financing forms with very long tradition, especially in countries with a large agricultural sector, like Belgium, the Netherlands, the United States and Hungary. Hungary has 150 years long history in this field. In the period between the political system change in 1990 and the EU accession in 2004 the Public Warehousing and the Lombard Financing became a true success story in the financing of the agricultural products. Regarding the agricultural and food sector size in the economy of Vietnam, which has more than $6 \%$ of GDP-growth per annum, and which figure is much higher, then in cases of countries above, it seems a reasonable idea to create and develop this kind of business in Vietnam. The country has a huge production basis, one of the world leader producers and exporters in case of rice and coffee and the productivity shows increasing trend. (Figure1). This activity can be a completely new long-term investment with short ROI, based on a successful Hungarian know-how export.

Figure 1 The production area and quantity in Vietnam (1996-2015)

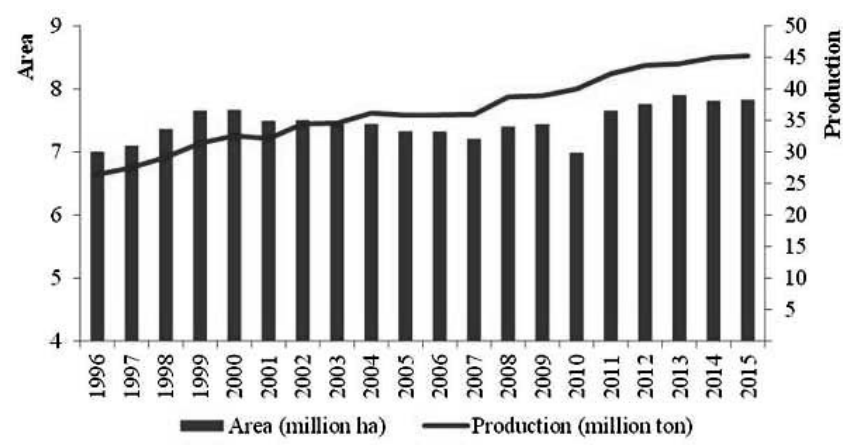

Source: Ministry of Agriculture and Rural Development of Vietnam (MARD)

Table 5: Hungarian agricultural imports from select countries of the Southeast-Asian region (USD)

\begin{tabular}{|c|c|c|c|c|c|c|}
\hline & 2010 & 2011 & 2012 & 2013 & 2014 & 2015 \\
\hline Brunei & 0 & 0 & 0 & 0 & 0 & 0 \\
\hline Indonesia & 2.986 .126 & 5.494 .265 & 4.629 .240 & 3.645 .508 & 4.986 .760 & 4.638 .023 \\
\hline Cambodia & 64 & 136.852 & 478.686 & 269.120 & 1 & 178.089 \\
\hline Laos & 0 & 0 & 0 & 12.002 & 0 & 24.444 \\
\hline Myanmar & 0 & 0 & 0 & 0 & 0 & 35.538 \\
\hline Malaysia & 9.689 .765 & 18.161 .981 & 17.411 .840 & 16.262 .527 & 17.080 .064 & 16.002 .502 \\
\hline Philippines & 424.695 & 200.260 & 665.962 & 711.659 & 751.070 & 1.575 .175 \\
\hline Singapore & 278.482 & 572.146 & 436.081 & 351.735 & 482.038 & 237.967 \\
\hline Thailand & 4.956 .452 & 4.666 .627 & 4.019 .210 & 4.418 .025 & 3.744 .350 & 2.726 .978 \\
\hline Vietnam & 4.677 .554 & 5.514 .646 & 4.024 .144 & 3.456 .142 & 4.916 .219 & 4.378 .695 \\
\hline ASEAN total & 23.013 .138 & 34.746 .777 & 31.665 .163 & 29.126 .718 & 31.960 .502 & 29.797.411 \\
\hline Total Hungarian agro-imports & 4.923 .470 .630 & 6.188 .377 .799 & 5.730 .419 .399 & 5.932 .331 .564 & 6.206 .151 .597 & 5.386 .171 .239 \\
\hline ASEAN proportion of the above & 0,47 & 0,56 & 0,55 & 0,49 & 0,51 & 0,55 \\
\hline
\end{tabular}

Source: Own compilation from data of the Research Institute of Agricultural Economy (AKI), Budapest, 2016 
Due to the complexity of Public Warehousing activity, in case of a successful implementation, this presence can also help a few Hungarian enterprises, operating in related fields of business to enter the markets of the Southeast Asian region. Based on the current information available, the potential dimensions of the Public Warehousing market can be illustrated just in the cases of the three most important agricultural products (see in Table 6). Thus, the value of the three main agricultural products is nearly USD 27 billion every year and it is increasing year by year. Furthermore, Vietnam imports 5-6 million tons of wheat in value of USD 1.5 billion may also be involved in Public Warehousing. The Hungarian grain market ranges about 10-12 million tons/ year, in value it means approximately USD 2.8 billion, that is only one tenth of the Vietnamese, and even less than just the Vietnamese coffee market by USD 1.2 billion. Before Hungary joined the European Union - in the EU's pre-accession period - noticeable amount of liquidity (HUF 200 billion $\approx$ USD 690 million) was involved into the Hungarian underfinanced agricultural market by Public Warehousing based Lombard credits annually, which was a major help to the production sector. The creditability of the agricultural sector was very low at that time due to the traditional approach of banks.

Table 6: The most important agricultural products in Vietnam, 2016

\begin{tabular}{|c|r|r|r|}
\hline Product & $\begin{array}{c}\text { Production } \\
1,000 \text { tons }\end{array}$ & $\begin{array}{c}\text { Price } \\
\text { USD/tons }\end{array}$ & $\begin{array}{c}\text { Value } \\
\text { million USD }\end{array}$ \\
\hline Coffee & 1,700 & $\sim 2,300$ & 4,000 \\
\hline Rice & 46,000 & $\sim 460$ & 21,000 \\
\hline Corn & 6,000 & $\sim 260$ & 1,600 \\
\hline Summa & 53,700 & - & $\sim 26,600$ \\
\hline
\end{tabular}

Source: Own compilation from data of: ICE, NASDAQ, IG UK, CME Group, FAO.

Based on the Hungarian and European experience, 65\% of the yearly harvest was stored and financed by producers, traders and processing companies. Approximately $35 \%$ of the whole production needed extra financing possibilities based on Public Warehousing. In the United States, which has one of the most developed PW system, this ratio is more than $50 \%$. There are no exact figures available from Vietnam at the moment, but, because of the current agricultural financing shortage, this proportion must be much higher! It probably reaches the level of 15-20 billion USD.

The Vietnamese agriculture sector, similarly to the Hungarian agriculture in the nineties, suffers of the lack of financing. The production sector has serious loss because of the partial lack of sufficient storage capacity, which causes more than one million tons of wastes just in case of rice, even more than the effect of the low dumping prices of both the rice and the coffee as well. Vietnam has the highest production level in ASEAN region as clearly illustrated in Figure 2, but it is not reflected in revenues, as Vietnamese average export prices are $30 \%$ lower than the same of Thailand according to our information.
Figure 2: Rice production, crop yields in Southeast Asian countries. 1980-2014
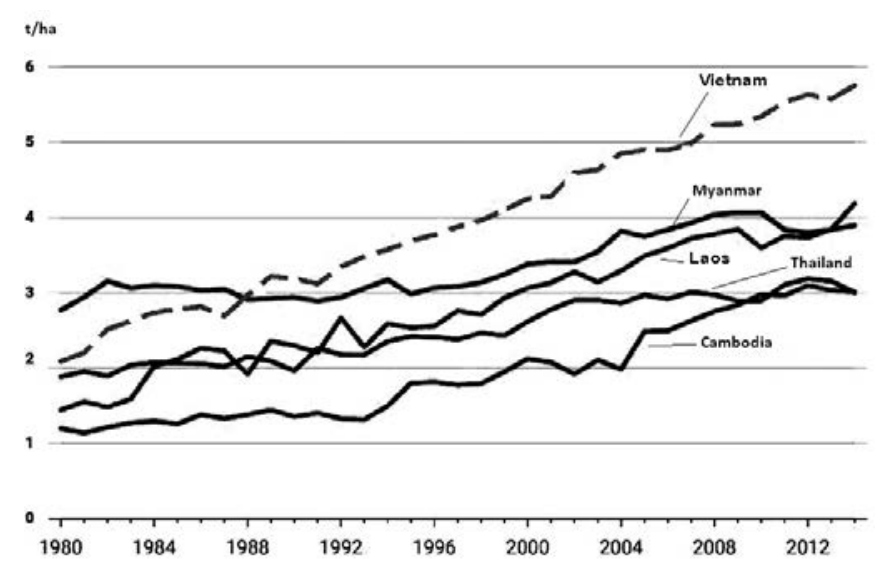

Source: Own compilation from data of FAO.

Taking into account of our experience and our investigations, the Public Warehousing sector which should be carried out with the cooperation of Hungarian firms and by their know-how export, could re-valorize these agricultural commodities which are produced at high standards and in large quantities. This would result in great success in the Vietnamese agricultural sector in one hand, and could open the way for a number of Hungarian companies to reach a new market of nearly 100 million people on the other hand.

The implementation of such a new and very significant development creates the opportunity of engaging in warehouse construction, logistic development, product handling and manipulation, ventilation, sanitation and other professional fields of development for Hungarian companies. The Lombard Financing system of commodities should be based on local banks primarily, but this market would open the possibility for Hungarian commercial banks, insurance companies and other financial servicing firms for involvement. Finally, mention must be made about one more significant point. A strong and successful Hungarian presence in Vietnam could be considered as a positive precedent and this pattern might be used for the exploration of the markets of other ASEAN countries.

\section{CONCLUSION}

The ASEAN region represents a small fraction of total Hungarian foreign trade. The growing weight and importance of the ASEAN countries in the world economy, their dynamic social and economic development should encourage Hungarian companies to find it worthwhile to be much more open to this region of the world. For Hungary today the ASEAN region is primarily still rather an import source than export market. Nevertheless, the region cannot be a principal target for agricultural or even industrial exports from Hungary, but the present results and figures could be further grown.

For the latter, the potential possibility we described in the last chapter of the study - in case of Vietnam, - could be a good example. 


\section{REFERENCES}

Brian,W.(2017): ASEAN shouldhavefourcountries withoveratrillion dollar GDP by 2030 (List of ASEAN countries' GDP). March 27, 2017 https://www.nextbigfuture.com/2017/03/asean-should-have-fourcountries-with.html

Economic Outlook for Southeast Asia, China and India 2016 Enhancing Regional Ties OECD, 2016, 34 p. http://www.oecd. org/dev/asia-pacific/SAEO2016_Overview\%20with\%20cover\%20 light.pdf

Erdei-Késmárki-Gally Sz. - Fenyvesi L. (2012): Tendencies and challenges in global agriculture. Problems of World Agriculture, Warsaw University of Life Sciences, Warsaw, 12 (XXVII) No 3: pp. 47-53.

Fact Sheet on ASEAN Economic Community Jakarta: ASEAN Secretariat, December 2015 ISBN 978-602-0980-65-2, 4 p.-ng nations), Külgazdaság, 1993. 4. 47-59 pp.

Kiss, J. (1993): Magyarország és a fejlődő országok gazdasági kapcsolatairól Külgazdaság, Vol. 1993 No. 4. 47. - 59. pp.

Külkereskedelem 2015. (Foreign Trade in 2015) KSH (Central Statistic office, Budapest), 15 July 2016, 15. p. https://www.ksh.hu/docs/hun/xftp/idoszaki/kulker/kulker15.pdf

Madlenak, R., Madlenakova, L. (2015). The Differences in Online Advertising Acceptance in China and Slovakia. In Proceedings of the 2015 International Conference on Management Engineering and Management Innovation (Vol. 3, pp. 45-49).

Neszmélyi, Gy. (1999.): Main Characteristics and Prospects for Foreign Trade Relations Between Hungary and the ASEAN Countries Hungarian Agricultural Research, Budapest, 1999, Vol. 8, Mo. 3. 19-22 pp. ISSN: 1216-4526.

Neszmélyi, Gy.: A magyar külkereskedelem Délkelet-Ázsiában (Macroeconomical trends of the Southeast-Asian countries). Gazdálkodás Vol. 15. No. 6., 1996. 55-60 pp.

Zéman, Z. (2017): A vezetői számvitel funkcionális kapcsolata a vállalati belsô kontroll környezettel (The functional relationship between management accounting and the internal corporate control environment). JURA, Pécs, Vol. 2017 No. 1. 193 - 198 pp. http://jura.ajk.pte.hu/JURA_2017_1.pdf

Zsarnóczai J. S. (1979): Gazdasági fejlődés és tervgazdálkodás Szíriában. (Economic development and planeconomy in Syria). MTA Közgazdasági Szemle (= Economic Review), No 9, September 1979,1103-1118. p., ISSN 0023-4346

Zsarnóczai J. S. (1997): Közel-Kelet élelmiszerhelyzetének kilátásai (= Perspective of food condition in Middle East). Gazdálkodás (= Agricultural Economy) 41 year, No: $11.55-61$ p. HU ISSN 0046-5518

\section{Other sources from internet:}

http://ap.fftc.agnet.org

https://www.cmegroup.com

http://www.nasdaq.com/

https://www.ice.com/

www.ig.com/uk

www.mard.gov.vn/en

www.eiu.com/ 